\title{
The Architecture of the Armenian Church and Convent
}

\author{
Thomas Kaffenberger
}

Until recently, the architecture of the Armenian Church has played a subordinate role in the study of the building, rather marginalized by the importance of the painted interior decoration as well as the intriguing historical context. ${ }^{1}$ The church is indeed modest in size, of a simple typology - a single, short nave with an apse-and only sparsely decorated with sculpted elements.

However, the elegance of the edifice as well as the high technical quality of the executed masonry tells a different tale. It testifies for the intended sophistication of the building, which was certainly more than a mere blank canvas for the (later) application of a painted cycle. ${ }^{2}$ In consequence, a more in-detail appraisal of the architecture seems promising in several kinds of aspects. In its first part, this brief study intends to highlight the architectural characteristics of the church and their accordance or discordance with other churches of medieval Famagusta and the crusader territories. This evidence will then be used to evaluate previously proposed dates of erection. The second part will focus on the surrounding structures, today all but disappeared, and attempt the reconstruction of their

T. Kaffenberger $(\bowtie)$

Department of Art History and Archaeology, University of Fribourg, Fribourg, Switzerland

(C) The Author(s) 2017

M.J.K. Walsh (ed.), The Armenian Church of Famagusta and the Complexity of Cypriot Heritage, Mediterranean Perspectives, DOI 10.1007/978-3-319-48502-7_6 
layout with the help of historic photographs and the results of the recent Ground-Penetrating Radar (GPR) investigation. ${ }^{3}$

\section{The Main Church}

The Armenian Church is a building of roughly $7 \mathrm{~m}$ width and $11.50 \mathrm{~m}$ length, entirely constructed from typical, local limestone ashlars. It consists of a rather high, oblong nave and a lower, recessed semicircular apse (Fig. 6.1). The exterior walls are structured by four shallow buttresses,

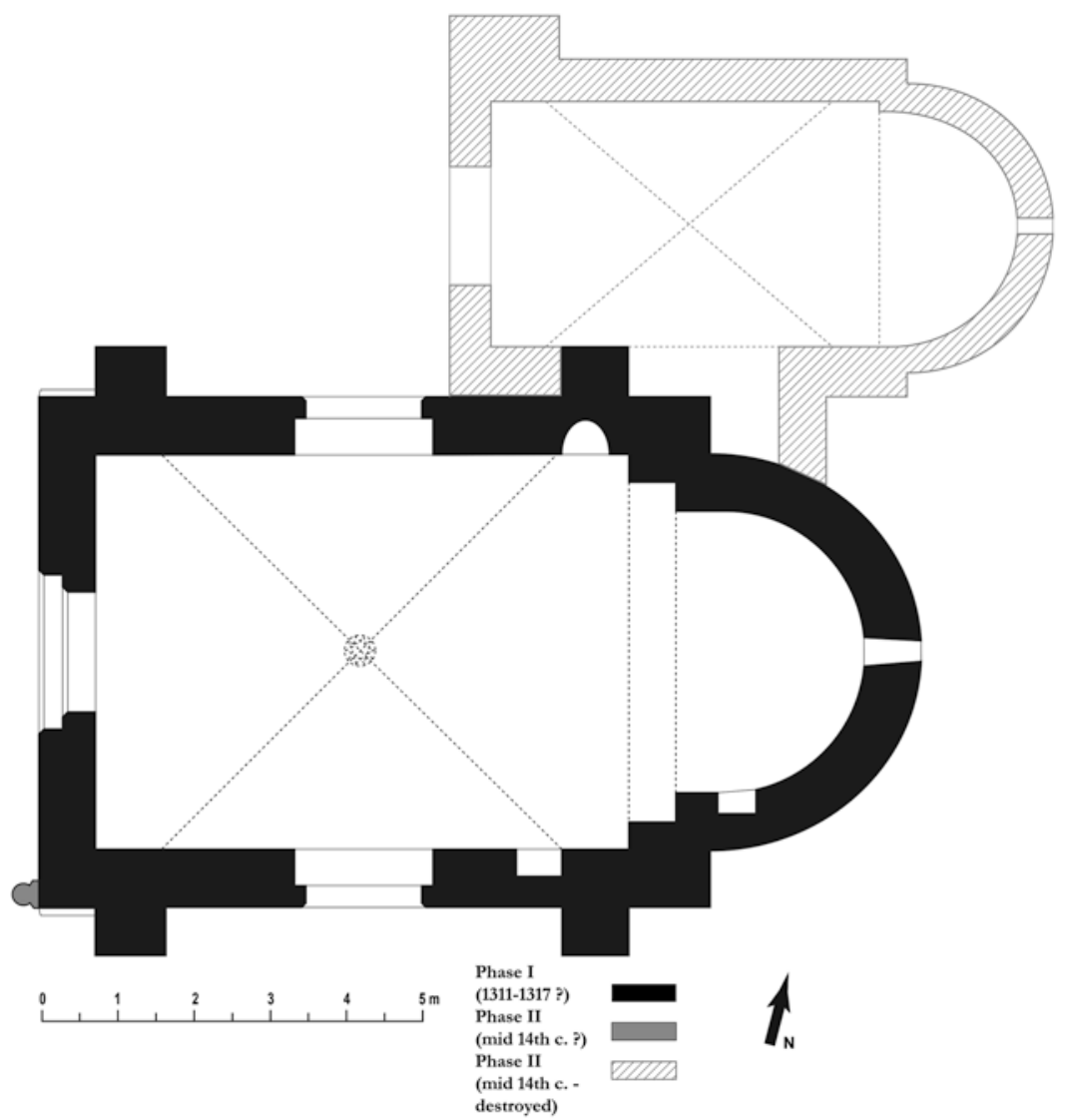

Fig. 6.1 Famagusta, Armenian Church, ground plan with reconstructed northern annex 
which are placed symmetrically, ca. $70 \mathrm{~cm}$ off the building corners on the northern and southern walls (Fig. 6.3). Access to the interior can be gained through three portals, one each in the northern, western, and southern walls. A single window with hood mold is situated above each portal, the one in the west being slightly shorter than the others. Gables surmount the walls and a profiled cornice clasps around the whole structure, including the apse.

The inside is only sparsely decorated as well. A simple but very wellexecuted square groin vault covers the only bay of the nave. As the bay itself is rectangular in shape, the groin vault continues seamlessly into small barrel-vaulted segments in the east and west (Fig. 6.2). The apse is offset against the nave with a stepped double recess; a profiled stringcourse runs along the base of the semi-dome and continues onto the triumphal arch. Three niches are placed in the northern and southern nave walls and

Fig. $\quad 6.2$ Famagusta, Armenian Church, interior toward east

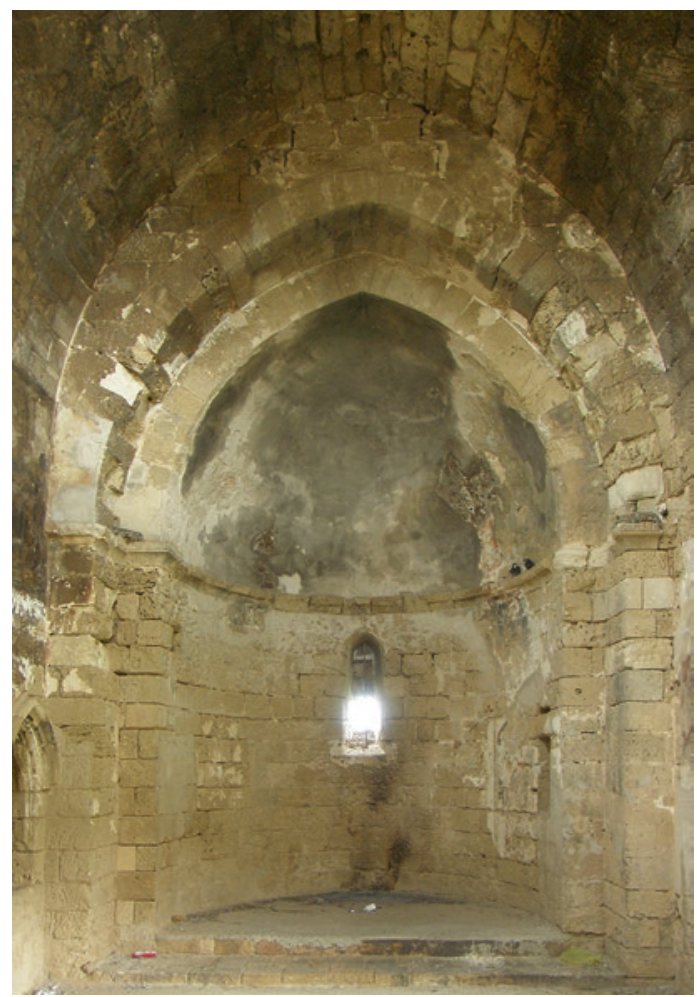


on the southern side of the apse. While the latter are simple, rectangular openings, the one in the northern wall shows a rich decoration-we will come back to this below.

\section{Restoration History}

Today, the church is in a structurally sound and overall intact state. ${ }^{4}$ However, the western gable, which is trapezoid, not triangular like the others, makes us wonder about the originality of this state. A drawing of 1862, executed by the architect Edmond Duthoit, reveals that the gable originally ended in a shallow belfry with two or three arched openings (Fig. 7.1). ${ }^{5}$ This fact should be a reminder of the heavily altered state of many churches in Famagusta, thus the use of historic pictorial sources proves to be indispensable. While the Duthoit drawing is the oldest of these and shows a largely intact building, a number of photographs taken in 1896 by Camille Enlart (Figs. 6.3, 6.4, and 7.2) and in 1911 by Lucien Roy (Fig. 6.8) add further evidence for the bad state of the church before and during the first restoration works. ${ }^{6}$ This is essential for the evaluation of building details, many of which had to be renewed or reconstructed. ${ }^{7}$ In 1896 , both, northern and southern portals, had lost their jambs and corbels, the southern one also the lintel and parts of the archivolt, which were still in place in 1862 . The western portal was still in a good state, while a gaping hole in the façade above bore testimony to the collapse of the belfry. All window frames were damaged and the apse vault had partly collapsed. The rapid deterioration of the building came to a halt in the early 1900s, when the northern and southern walls were repaired (without a reconstruction of the portals) and the western portal stabilized. The roof, however, remained untouched until the interventions from 1937 onward, directed by Theophilus Mogabgab, then director of the Antiquities Office in Famagusta. ${ }^{8}$ Mogabgab opened the lateral walls again and, partly using the scattered stone material, reconstructed both portals. Furthermore, his workers closed the gaps in the roof and façade and replaced weathered stones (Fig. 6.5). The cornice seems to have been entirely renewed, but based on the design of few remaining fragments. On the inside, this restoration left fewer traces. Only the new upper part of the apse vault and single stones in the nave vault originate in the 1930s rather than in the medieval period. The restoration was accompanied 


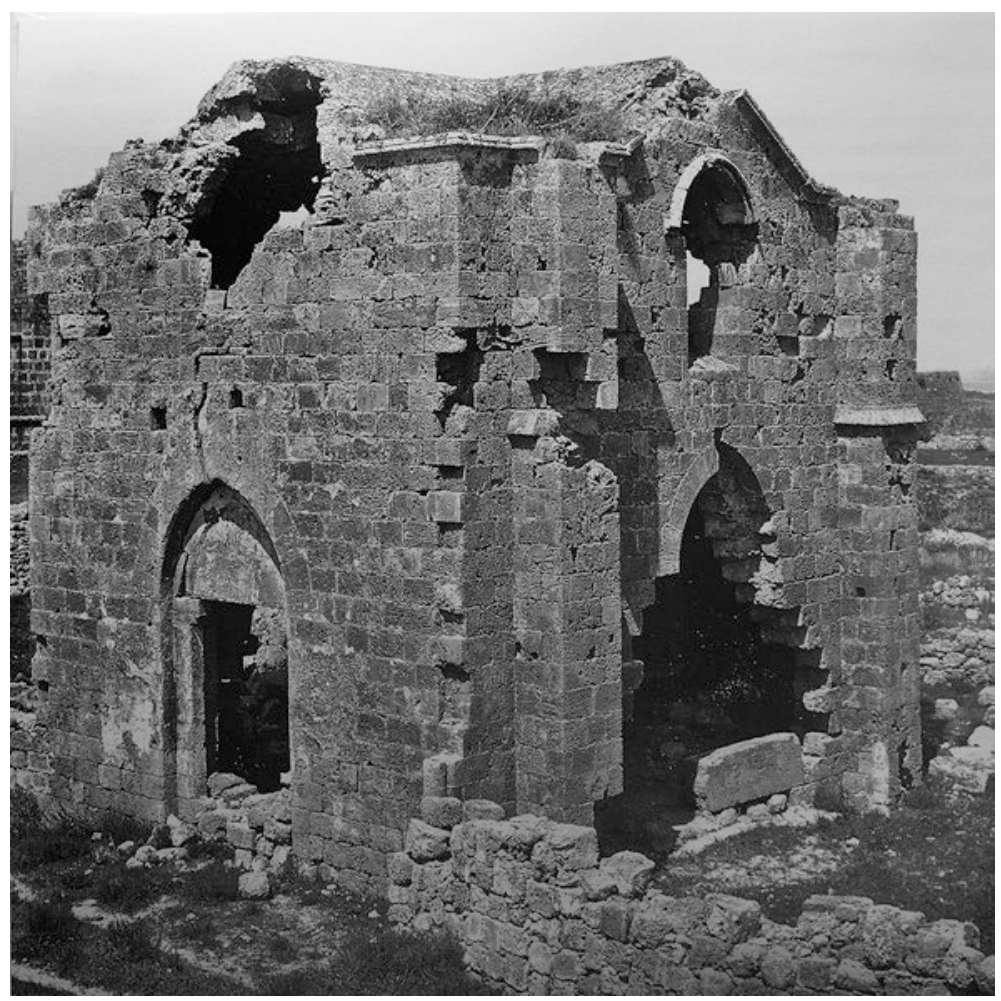

Fig. 6.3 Famagusta, Armenian Church, from southwest, photograph by Camille Enlart (1896)

by an excavation of the surrounding building foundations, which was sadly not documented and is today only tangible through few photographs taken after the clearing of the site.

\section{Typological and Stylistic Comparanda: Famagusta and the Crusader Levant}

As has been remarked before, the Armenian Church, albeit in accordance with the general aesthetics of medieval church building in Famagusta, features several unique traits that need to be explained. ${ }^{9}$ Already the 




Fig. 6.4 Famagusta, Armenian Church and Carmelite Church, from northeast, photograph by Camille Enlart (1896)

moderate size and the resulting single bay of the nave surprise. In Famagusta, only the southern church of the so-called Twin Churches is comparable in its proportions and typology; it also consists of a groin-vaulted nave and a semicircular apse. ${ }^{10}$ However, it lacks the elegance of the Armenian Church, as the exterior shows nothing but a plain cube without gables or buttresses. ${ }^{11}$ The combination of gables and buttresses indeed stands out among the smaller churches of Famagusta. Most other buildings are, just like the southern Twin Church, entirely plain from the outside-even if gables adorn, among others, the churches of Saint Epiphanios and Saint Nicholas of the Greeks. ${ }^{12}$ Only the church of Saint George Exorinos, originally a single nave church of three bays, features both buttresses and gables. ${ }^{13}$ Especially the added northern aisle bears close resemblance to the situation of the Armenian Church: here, the buttresses are not placed at the building corners, but offset by half a meter. Furthermore, they possess weathering with drip molds, even if these are much more pronounced than in the case of the Armenian Church. In both cases, the gables only 


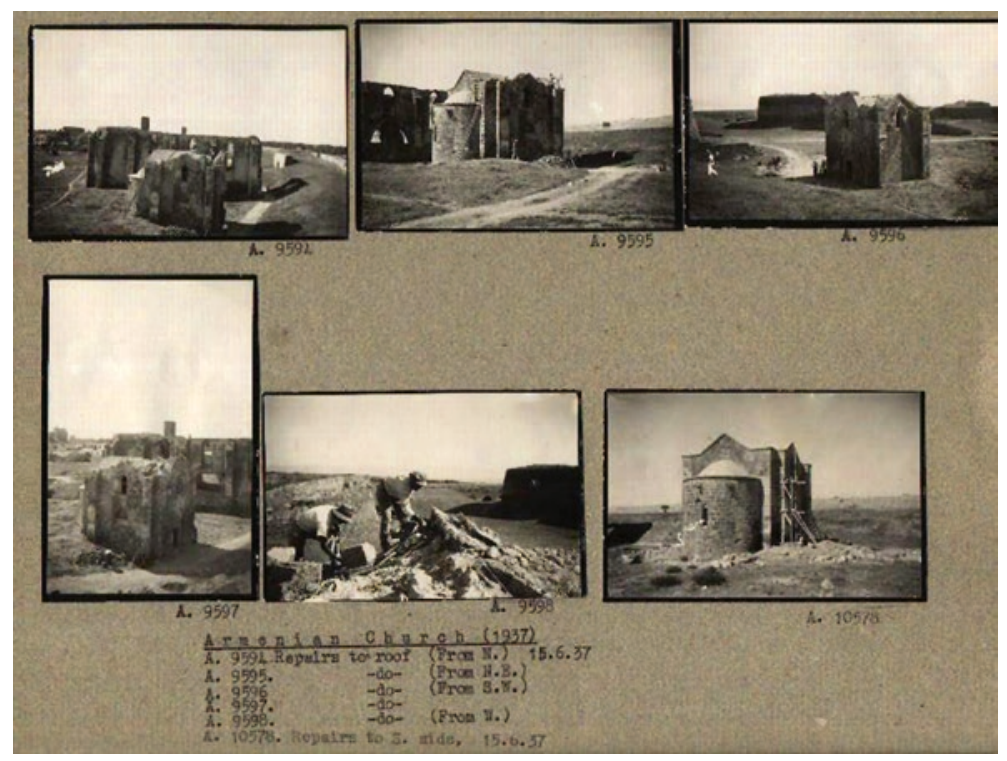

Fig. 6.5 Famagusta, Armenian Church Repairs 1937, Theophilus Mogabgab archive

stretch between the buttresses and the whole building features a continuous cornice.

The similarities extend to the interior, which is groin vaulted in a similar way as the Armenian Church. Here, as well, the groin vault is understood as the combination of two interpenetrating barrel vaults, which results in the abovementioned longitudinal continuity of barrel-vaulted compartments and in a horizontal apex of the vault. Apart from the Armenian Church, Saint George Exorinos and the southern twin church, also Saint Epiphanios, Unidentified Church No. 18 (aisles), Saint Nicholas of the Greeks and the unidentified church adjacent to the Venetian palace possess this type of groin vaults. ${ }^{14}$ The so-called Tanners' Mosque, a few meters south of the Armenian Church, is also groin vaulted, but the technique for the execution of the ridges differs: while the other vaults utilize L-shaped stones to link longitudinal and transversal stone layers, here the equivalent stones are chamfered and do not interlock-resulting in a joint along the ridge. Furthermore, the vault apex forms a curve and the quality of execution is much worse. Remarkably, the superior aesthetics of the 
supposedly older type of groin vaults was copied here by applying fake joints, carved in regular intervals into the irregular vault stones. This rather elaborate imitation might well mean that the vault masonry of the Armenian Church, but also of other similar buildings, remained visible, probably only covered with a thin layer of translucent lime wash. ${ }^{15}$

The portals and windows of the Armenian Church draw a similar picture. The main portal is recessed by one step, which forms a pointed arch. The doorway itself is rectangular with small profiled corbels. The tympanum above is set back by a small chamfer that continues from the jambs onto the frame of the tympanum. Especially the simple arched recess is revealing as it is a rather uncommon type among the portals of Famagusta. The closest relative is the central-western portal of Saint George Exorinos, even if here the chamfer ends in extremely shallow profiled corbels below the tympanum. The Armenian's corbels share some features with those of the northern portal in Saint George Exorinos: a thin orthogonal line, setting off the corbel against the rest of the same ashlar, and a roll-and-hollow profile with thin quirks. The northern and (reconstructed) southern portals of the Armenian Church are much simpler: a rectangular doorway, surmounted by a lintel and an arched recess. Apart from the quarter circle corbels, also with the characteristic orthogonal frame, these portals imitate a traditional local type, which was widespread since the middle Byzantine period. For the windows, once more a look at the Exorinos church is helpful. Both edifices share simple, strongly chamfered window frames. The profiled hood molds of the Armenian Church find their counterpart in the main apse window of Saint George Exorinos, here slightly flatter but of a similar profile (roll-and-fillet/hollow/roll).

The same type of hood mold adorns the elaborate niche in the northern wall, which shows that here the original idea of an exterior feature (window, portal) was transferred onto this interior feature (Fig. 6.6). The damaged tracery that fills the pointed arch of the niche (with a single roll framing it) might be the only element of the church, which points toward a different group of buildings: it resembles the elegant tracery of the northern portals of the Latin cathedral of Saint Nicholas as well as of the northern Twin Church. The same type of cusped tracery was used occasionally as window filling in Famagusta (e.g., in the Unidentified Church No. 18) and other places. ${ }^{16}$

The profile of the apse stringcourse, a simple quirk and hollow, in contrast, fits again well within the previously described context. Similar profiles are known from the side apses of Saint George Exorinos and the 


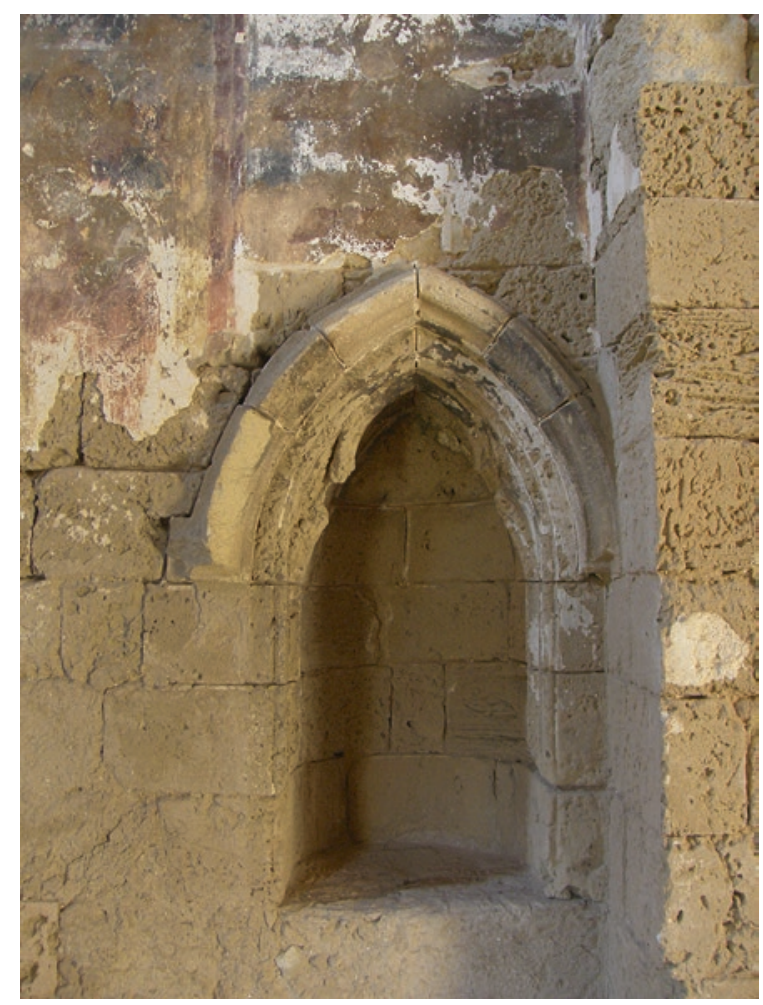

Fig. 6.6 Famagusta, Armenian Church, decorated niche in the northern nave wall

cornice of Saint Epiphanios, but in both cases the cavetto motive is less explicit than in the Armenian Church.

For closer comparanda, we have to broaden the geographic horizon of the investigation. Already Michele Bacci has suggested the architecture of the Crusader Levant as possible inspiration for the groin vaults, especially those of Saint George Exorinos. ${ }^{17}$ However, he sees the main source for features such as the compact building type and the stepped bema/triumphal arch in the churches of Armenian Cilicia. ${ }^{18}$ While it is certainly true that most known churches from Armenian Cilicia represent the compact single-bay type with apse, only a few of them indeed possess a stepped bema (Sis, Chapel U in Korykos). On the other hand, many of the larger churches 
in the Levant employ a stepped triumphal arch: for example, Notre-Dame in Tortosa and Saint John in Giblet, to name just the most prominent and best-preserved buildings. ${ }^{19}$ Apparently, also smaller (albeit aisled) churches made use of the same element, as is shown by the examples of Saint Phocas in Amioun and of the excavated parish church of Tall Qaimun. ${ }^{20}$ In Amioun, we also encounter the quirk and hollow profile of the Armenian's apse stringcourse, here surrounding the nave piers. ${ }^{21}$ Furthermore, elements of the portals and windows are paralleled by examples in the Levant. A simple arched recess frames the northern portal of Notre-Dame in Tortosa; quarter circle corbels with a rectangular frame support its lintel. The southern portal, in contrast, is surmounted by a profiled hood mold, a feature that is relatively widespread in the Crusader Levant. Finally, this suggestion of a certain link of the Armenian Church with a portfolio of architectural forms from the Crusader Levant is strongly supported by a curious detail of the otherwise widespread groin vault (Fig. 6.7). On its apex, the vault features a sculpted keystone which shows a centrifugal foliage decoration.There is no second fourteenth-century example for a decorated keystone in a groin vault in Cyprus, whereas this type of decoration is prominently displayed

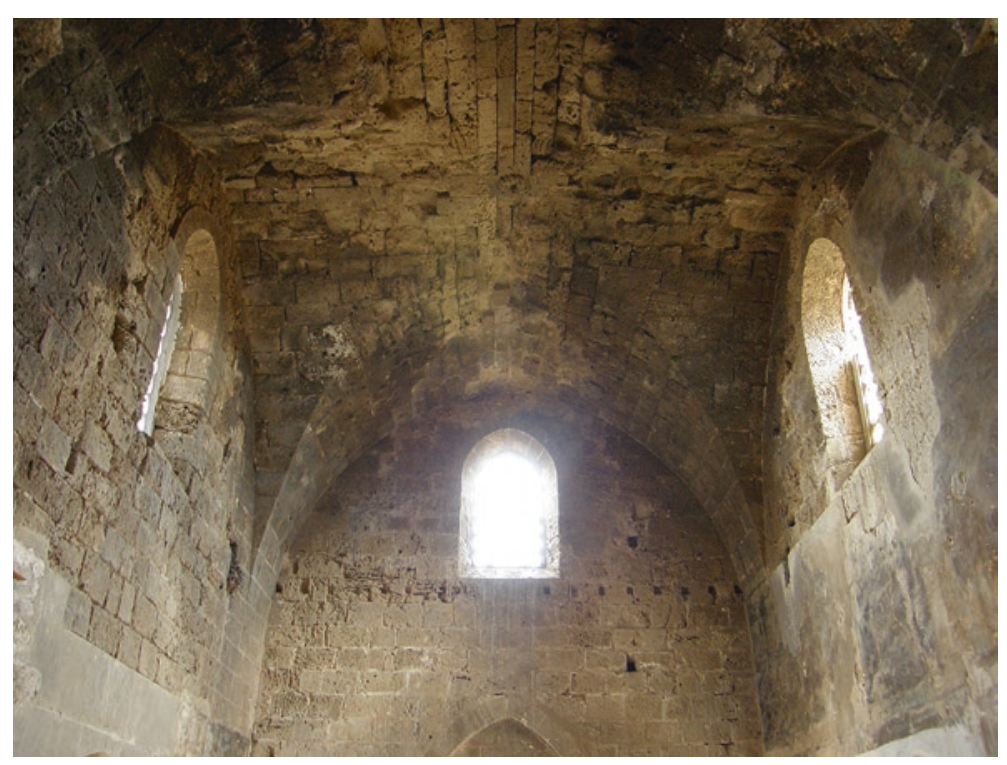

Fig. 6.7 Famagusta, Armenian Church, vault toward west 
in six aisle bays in the church of Our Lady of Tortosa-some of these with comparable foliage patterns. ${ }^{22}$

It is further worth noting that the small Armenian Church of the Savior in Jerusalem, despite not employing many of the decorative elements present in Famagusta (except for hood molds above the windows), bears a surprising typological resemblance. It is a single-space church as well, approximately $14 \mathrm{~m}$ long and $9 \mathrm{~m}$ wide, with a semicircular apse, a seamless groin vault (here not aligned with the lateral walls) and a (deeper) stepped arch separating the nave and the apse. ${ }^{23}$

Overall, the centralized character and steep proportions of the building remind us of the Armenian building traditions, even if the church lacks a dome. In addition, the position of the niche in the northern wall finds numerous counterparts in Armenian Cilicia. ${ }^{24}$ However, the building technique, and the decoration largely make use of elements deriving from the Levantine Crusader architecture-even if recombined in an unusual, entirely local manner.

\section{Date and Historic Context: An Attempt}

The last and maybe most complex issue that has to be raised during a formal analysis is the date of the building. Two differing suggestions have been made so far: Enlart, the first scholar who discussed the church in detail, refers to two pilgrim's accounts mentioning a wave of Armenian refugees arriving in Famagusta in 1335 and 1346. ${ }^{25}$ According to him, the erection of the church would have been a consequence of these events, thus placing it in the second half of the fourteenth century. Philippe Plagnieux and Thierry Soulard recently rejected this date and opted for the years 1311-17. This date is mentioned in a bulla (papal decree or charter) of Pope Clement V, which grants indulgences for the erection of an Armenian church dedicated to the "Virgin of Sorrows" (or, a less likely translation, "Sainte-Marie-Vert") during this timespan. ${ }^{26}$ While Michele Bacci did not challenge this interpretation, first Allan Langdale and Michael Walsh, then more recently Michalis Olympios, tended toward a date later in the fourteenth century. ${ }^{27}$ Olympios rejects the identification of the current building with the monastery mentioned in the sources, pointing out a certain insecurity due to the attested presence of further Armenian churches in the city (namely the cathedral, Saint Sergius, Saint Barbara, Saint Leonard). ${ }^{28} \mathrm{He}$ instead places the church within a group of buildings which show a strong "Crusader Revival" style, employing 
outdated twelfth and early thirteenth century forms from, according to his opinion, the mid-fourteenth century onward..$^{29}$

Crucial for the interpretation of the Armenian Church is, as we saw, the larger (Syriac) church of Saint George Exorinos - the date of which is also strongly disputed..$^{30}$ If we assume that Michele Bacci is right in placing the main nave in the late thirteenth century, as a direct result of the arrival of refugees from conquered Tripoli, the aisles would have been built not much later, probably during the first decades of the fourteenth century. ${ }^{31}$ If we then accept that the stylistic similarities are indeed significant enough to place the Armenian Church in the same period, the 1311-17 date seems far from improbable. ${ }^{32}$ It would indeed be rather early, especially with regard to the northern niche taking up on an absolutely contemporary tracery model and making use of a framing roll, a feature that is otherwise not attested for buildings of the $1310 \mathrm{~s} .{ }^{33}$ However, a decisive element, which both churches have in common, supports the tendency toward an early date: external buttresses seem to disappear from the architectural canon of urban Famagusta already before the mid-fourteenth century, making place for entirely plain buildings such as the southern Twin Church.

Of course, this proposal of an early date is based rather on indications than on irrefutable evidence and leads to a number of further questions. First, how would the transmission of the style have functioned? Would it nevertheless have been a "Crusader Revival," thus a purposeful use of outdated forms only more known from drawings and/or older buildings in lost territories? Or rather, in this case, a "Crusader Survival," an afterlife of forms established in the Levant and brought to Cyprus by the refugees? ${ }^{34}$ If we accept the early date in the 1310 s, the latter might have been the case. This, however, does not explain conclusively, why the church is rather oriented toward the Latin architecture of the Levant and not traditional or contemporary Armenian architecture. Thus, we have to wonder, who was responsible for the design of the church. Perhaps, we will not go wrong to imagine a dynamic dialogue between the individual protagonists: a master mason, the patron(s), probably also the monastic community or the bishop, if not already among the patrons. In the multifaceted, dynamic environment of fourteenth-century Famagusta, it is hardly thinkable that Syrians, Armenians, and other smaller religious communities all entertained their own team of masons and workmen-after all, the erection of the individual buildings probably did not last longer than a few years and would not have required the constant attention of the more specialized masons. Thus, we would rather have to imagine "teams 
of masons practicing a common stylistic idiom, yet working from a variety of different plans to suit the needs and wishes of their multi-ethnic and multi-creed patrons." 35 Furthermore, it is probable that each site was guided by a specialized master mason with a specific training background. On the site of the Armenian Church, this (purely hypothetical) master mason may have still been familiar with the buildings in the Levant, or at least an earlier (now lost) building in Famagusta, and might have contributed the Levantine elements of design for this building, yet adapted to serve the specific needs of the Armenian community. ${ }^{36}$

\section{The Northern Annex: A Funerary Chapel?}

In any case, several years after the completion, a second chapel was added onto the original building (Fig. 6.1). Today, nothing remains of this chapel except for few marks left on the masonry of the northeast corner of the main church. However, the chapel is still visible in a photograph taken by Camille Enlart (Fig. 6.4), who describes the structure as "a second chapel ... of which all that remains is an insignificant apse with Gothic mouldings on the cornice." ${ }^{37}$ Indeed, around 1900 the apse was still fully preserved. It was lower and smaller than the apse of the main church, but protruded further to the east. The eastern wall of the chapel nave seems to have been more or less aligned with the apex of the older main apse; it was surmounted by a low triangular gable. Slit-like windows pierced the apse as well as the gable above. Enlart's photograph still shows the precariously reduced rests of the northern wall of the chapel, plain without buttresses and surmounted by a triangular gable, which rose higher than the eastern one. A wall fragment further to the west seems not to be aligned with the rest of the wall but rather to be the rest of a protruding element.

Large fragments of plaster on the northeastern buttress of the main church as well as on a detached, crumbling pier next to it, reveal that the new chapel did not receive a continuous southern wall, but made use of parts of the older wall. In its southwestern corner, a new pier was built against the older wall to compensate the depth of the buttress next to it. This additional pier also explains the conspicuous change in color of the masonry of the wall behind, forming a vertical line. The pier, it seems, covered the original mortar of the joints and, perhaps, a light lime wash, which both vanished on other uncovered parts of the building. Even if already then nothing was left of the chapel's western wall, the line might well mark its position, directly east of the northern portal of the main 


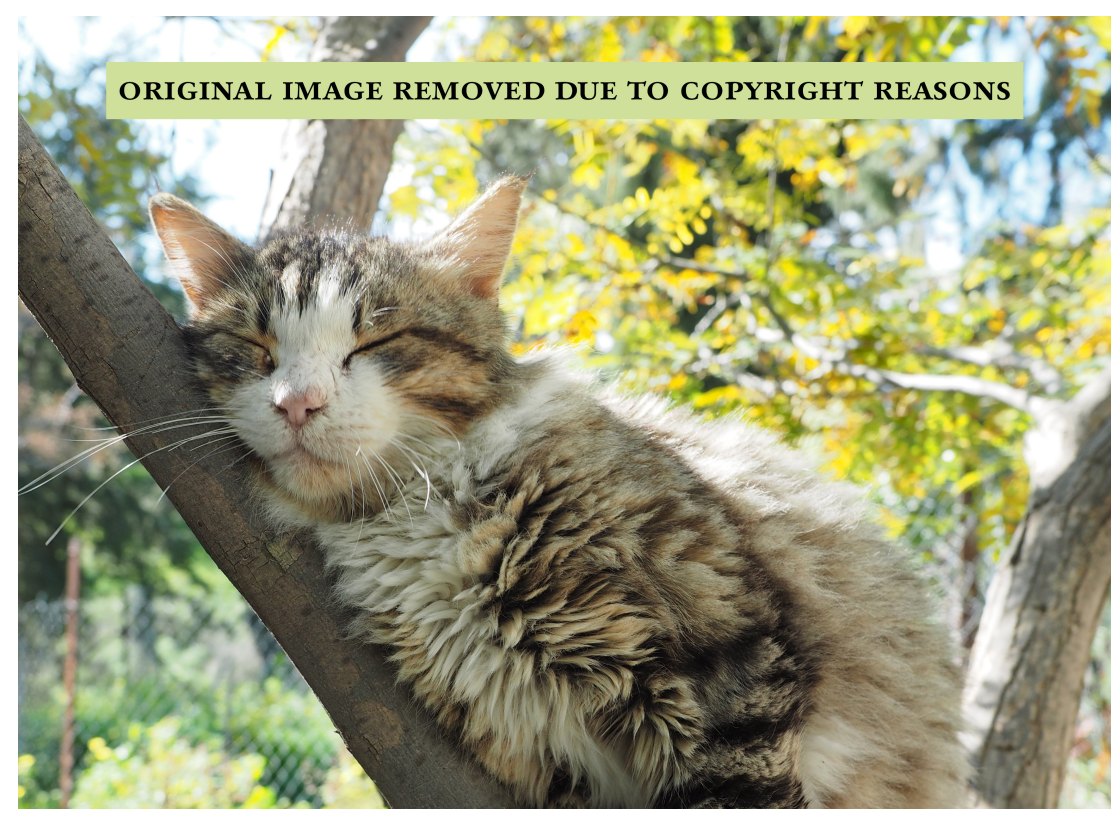

Fig. 6.8 Famagusta, Armenian Church and Carmelite Church, from northwest, photograph by Lucien Roy (1911)

church. In fact, the line is still visible and so are the fragments of the plaster on the buttress and few stones of the added pier.

All parts of the western end of the church had vanished in 1911, when Lucien Roy took several pictures of the complex (Fig. 6.8). One of these is the only one to show the inside and the remains of vaulting of thenow further reduced-fragments of the chapel. On the southern wall, the imprint of a rather steep arch is visible, which spans over the buttress of the older church.

We can still see this arch imprint on the buttress today, ending in a gap in the buttress masonry: here a part of the older masonry had been removed to interlock it with the new vault. Next to this, a fragment of a curved vault remained, proving the existence of a groin vault of the usual type (i.e., with barrel-vaulted longitudinal extensions).

The rather unusual layout of a short, almost square, nave is confirmed by the recent GPR tests as well as historic images taken during the excavation of the site. ${ }^{38}$ Here, the west wall of the chapel, indeed just east from 
the older northern portal, is as easily discernible as the protruding apse and parts of the northern wall. The only problematic part of the structure is its northwestern corner. On the GPR images (Fig. 10.2), it seems that a rectangular annex was situated in the center of the northern wall, whereas the historic images reveal the solid foundations of a rectangular salient on the corner, matching the position of the wall fragments on Enlart's image. Strangely, no sign of an annex in the center of the wall is visible on the photographs. Until further excavations, it will not be possible to prove the extent and precise shape of the rectangular salient-was it just a buttress, perhaps added at a later date? The thought of a niche would be intriguing, but the location in the corner of the chapel more than unlikely. In any case, the evidence reminds us that GPR images require careful interpretation when it comes to building details.

Overall, the architecture of the chapel indicates a date somewhere in the mid- to late fourteenth century. Could this building be a consequence of the Armenian refugees from Layasso, arriving in Famagusta from 1335 onward, as suggested by Enlart for the main church? It is certainly possible, but the strict separation of the two structures surprises: the chapel was not built as an extension due to lack of space but to serve a distinct, separate purpose. It might be worth considering an interpretation of the chapel as a memorial building. In fact, there are several Cypriot examples for similar (but usually domed) chapels added onto an older church building, usually serving a specific commemoration or worship: Saint Anastasios in Peristerona or the Panagia Diakonousa in Prastio Avdimou to name but a few. Furthermore, separate chapels serving as martyria or mausoleums were extremely common in the Armenian monastic culture as well as in the context of episcopal sees. ${ }^{39}$ Of course, this suggestion has to remain conjectural, as we neither know of a specific veneration of a saint nor of a prominent patron that could be connected to the Armenian community of Cyprus in the mid-fourteenth century.

\section{The Monastic Precinct: Gathering the Fragmentary EVIDENCE}

Even Enlart's photograph shows little more than foundation walls remaining of the surrounding monastic buildings (Fig. 6.4). These foundation walls vanished before 1911 but were uncovered in the late 1930s-and are again underground, as the results of the GPR analysis showed. 
To the west of the church, the Mogabgab excavation uncovered a wall running parallel to the west façade of the church. To the south, it ended on the axis of the southeastern corner of the church. There, we can still see a curious feature: a semicircular respond, probably once supporting an arch above. The interpretation of Langdale and Walsh, who suggested a wooden porch and a corresponding respond on the northwestern corner, might need to be revised as the second respond most likely did not exist (neither can we find beam holes for the positioning of the porch roof in the façade). Probably, a second respond was instead attached to the uncovered wall which might have been part of a small courtyard. This courtyard would have been open toward the south and the arch might have marked the border between two separate areas of the precinct. Further west, Mogabgab's photographs show a paved area, but no door opening in the wall-was this the western end of the precinct and an adjoining road? To the north, the courtyard continued further than the church and perhaps opened up toward a second court in front of the later chapel-even if here neither the photographs nor the GPR prove to be helpful. The general situation east of the church seems clearer as the walls were in a better state at the beginning of the century (Fig. 6.9). A rectangular, corridor-like space, oriented in east-west axis, adjoins the apse of the main church. To the north of this, an obliquely positioned building contained at least three rooms with a smaller corridor (or separate small rooms?) to the west. To the south, two or three adjoining larger rooms in north-south axis are recognizable, followed by smaller rooms, which at a brief glance might also resemble a second corridor in east-west axis.

As we see in Enlart's photograph, this area was heavily disturbed by a modern access way in 1896, so even the 1930s restoration of the walls might not be entirely trustworthy. Furthermore, when the image suggests that the central smaller room was accessible from the north, the result of the GPR shows exactly the opposite, thus here the different parts of the evidence are irreconcilable. A large room adjoining the north wall of the Carmelite Church concludes the traceable structure to the south.

A detailed interpretation, or an attempt to assign functions to individual rooms, seems hazardous if based only on the presented evidence. A comparison with Armenian monasteries of the same period seems hardly fruitful: as Thierry underlines-here for the case of northeastern Armenia-there was no stringent building program for late medieval Armenian monastery compounds. ${ }^{40}$ Furthermore, the preserved and thus studied evidence is mainly restricted to rural areas and spares out the 

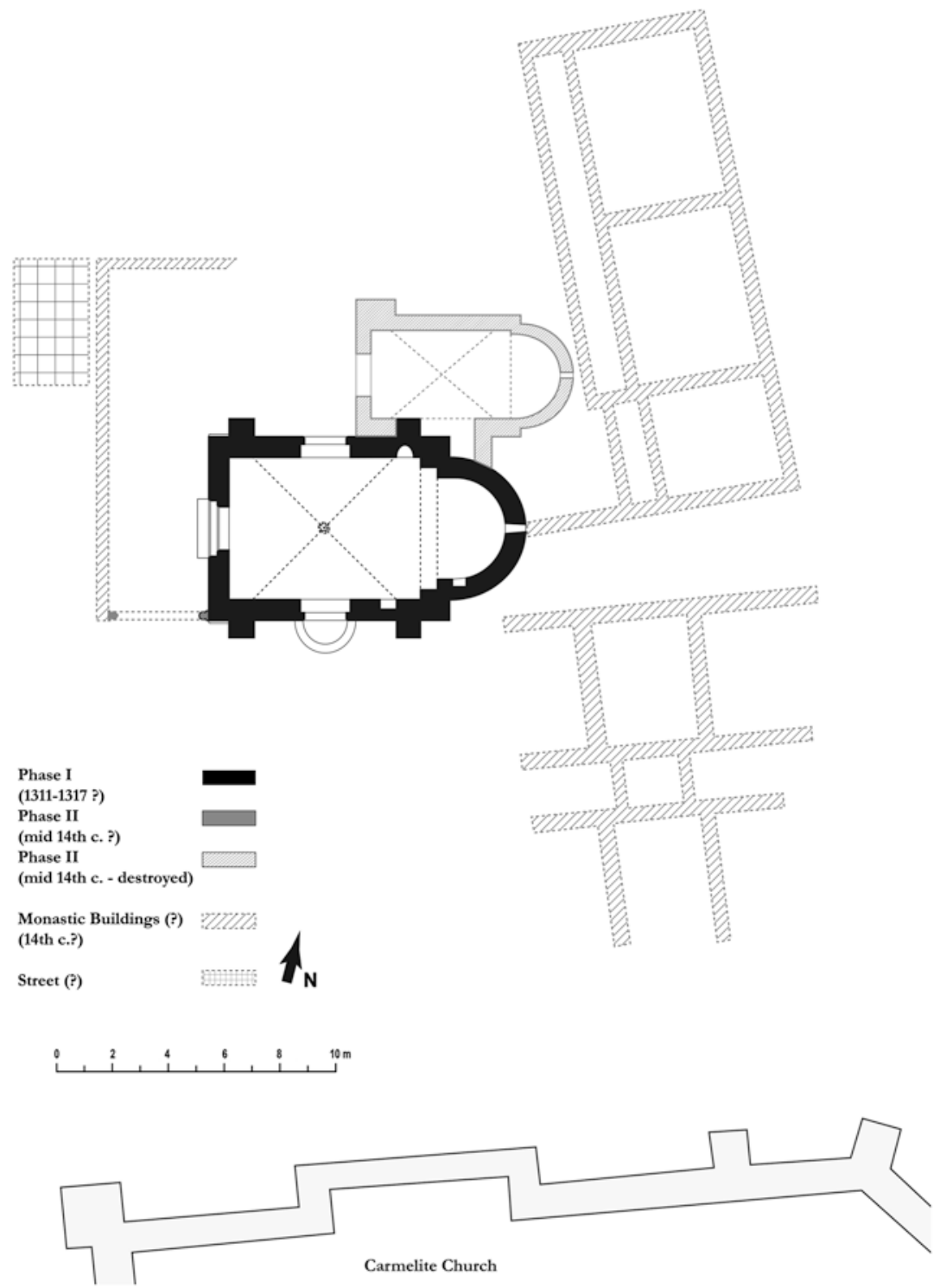

Fig. 6.9 Famagusta, Armenian Church and convent, site plan 
territory closest to Cyprus: Cilicia. There, most of the large and famous late medieval monasteries are entirely lost, to the point that not even the location of some is known today. ${ }^{41}$ The situation in the Levant is better, but here the constant change of the urban fabric in cities such as Jerusalem makes it almost impossible to grasp the original layout of the monasteries of, for example, the Holy Archangels or Saint Savior. ${ }^{42}$ In addition, as Enlart's images show, many of the remaining walls were fairly recent, stacked up from loose ashlars to mark the compound. Thus, it is impossible to evaluate if every wall that was uncovered and restored by Mogabgab indeed formed part of the medieval building complex. Furthermore, neither photographs nor GPR help to identify building phases or access ways.

Nevertheless, the evidence is comprehensive enough to suggest certain general patterns of usage (Fig. 6.9). The complex was irregular, resembling, for example, the well-studied unidentified monastery north of Omirou Street in the old town of Rhodes. ${ }^{43}$ The Armenian precinct probably had several entrances, linking the buildings with the public streets. The main access might have been possible through the wider corridor or lane in the east, which could have led (through a gate room?) onto a courtyard south of the church. From there, one would have been able to enter the church through the southern portal (which possessed a monumental, semicircular flight of stairs in front) or proceed further into the monastic compound through the archway in the west. Following this assumption, the building northeast of the church could have been part of the inner monastery while the other structures further south would have served different, more public, purposes.

To conclude, before further excavations might shed more light on the remains, it only seems safe to claim that the surrounding buildings were integrated within a dense, urban pattern. If they were indeed part of a monastic establishment, and there is no specific reason to doubt this, it did not follow a regular plan but adapted to the available space in the densely populated walled city of Famagusta.

\section{Notes}

1. The most important contributions dealing with the architecture of the Armenian Church are: Camille Enlart, L'art gothique et la renaissance en Chypre, 2 vols. (Paris: Leroux, 1899), 365-8; Camille Enlart, Gothic art and the Renaissance in Cyprus [L'art gothique et la Renaissance en Chypre], trans. David Hunt (London: Trigraph in association with the A.G. Leventis 
Foundation, 1987), 286-8; Philippe Plagnieux and Thierry Soulard, "Famagouste. L'architecture religieuse," in L'art gothique en Chypre, ed. Jean-Bernard De Vaivre (Paris: Boccard, 2006), 121-296, 257-60; Michele Bacci, "The Armenian Church in Famagusta and its Mural Decoration: Some Iconographic Remarks," Hask hayagitakan taregirk 11 (2009): esp. 490-91; Allan Langdale and Michael J.K. Walsh, "The Architecture, Conservation History, and Future of the Armenian Church of Famagusta, Cyprus," Chronos. Revue d'Histoire de l'Université de Balamand 19 (2009): esp. 19-21. I also wish to thank Michalis Olympios for valuable discussion and inspiring interchange.

2. Bacci, "Armenian Church," 490.

3. See Chap. 10 in this volume. I wish to thank Francisco Fernandes for sharing his results with me beforehand.

4. For the question of structural stability, see especially Chap. 11 of Andres Burgos Braga in this volume.

5. The drawing shows two arches and perhaps the springer of a third, destroyed arch-this is not entirely unequivocal. For Duthoit, see Lucie Bonato and Rita Severis, eds., Along the Most Beautiful Path in the World: Edmond Duthoit and Cyprus (Nicosia: Publisher, 1999), 195 and Chap. X of Lucie Bonato in this volume.

6. For Enlart see: Jean-Bernard De Vaivre, ed., Monuments médiévaux de Chypre: Photographies de la mission de Camille Enlart en 1896 (Paris: ACHCByz, 2012), 113-16; for Roy: Mediathéque du Patrimoine. The images of both are also discussed in detail in Chap. X of Lucie Bonato.

7. For a more detailed account of the restoration phases, see Langdale and Walsh, "Armenian Church," here 17-18.

8. Ege Uluca Tumer, "Twentieth-century restorations to the medieval and Renaissance monuments of Famagusta," in Medieval and Renaissance Famagusta: Studies in architecture, art and history, ed. Nicholas Coureas, Peter W. Edbury and Michael J.K. Walsh (Farnham: Ashgate, 2012), 217-34, here 228-30.

9. Plagnieux and Soulard, "Famagouste. L'architecture religieuse," here 260.

10. For the Twin Churches, see most comprehensively Jean-Bernard De Vaivre, "Identifications hasardeuses et datation de monuments à Famagouste le cas des 'églises jumelles des templiers et des hospitaliers'," Comptes rendus des séances de l'Académie des Inscriptions et Belles-Lettres 146 (2002). 
11. The cemetery chapel in Dali, on the other hand, possesses buttresses and gables, but was originally covered by an oblong rib vault. Furthermore, the apse is polygonal and the overall proportions are rather squat. (Enlart, L'art gothique,199-201; Enlart fails to recognize that the vaults and lateral gables are product of a nineteenth-century restoration.)

12. The name for Saint Epiphanios, the old church adjacent to Saint George of the Greeks, is not secured but used here in favor of the less likely "Saint Symeon." For this issue, see Thomas Kaffenberger, "Harmonizing the Sources: An Insight into the Appearance of the Hagios Georgios Complex at Various Stages of its Building History," in Coureas, Kiss, Walsh, Crusader to Venetian Famagusta: 'The Harbour of all this Sea and Realm,' 171-3.

13. For Saint George Exorinos most recently Thomas Kaffenberger, "Evoking a distant past? The chevron motif as an emblematic relic of Crusader architecture in late medieval Cyprus," in Proceedings of the MedWorlds Congress 2014 (forthcoming); Michele Bacci, "Syrian, Palaiologan, and Gothic Murals in the 'Nestorian' Church of Famagusta," Deltion tes Christianikes Archaiologikes Hetaireias 27 (2006); Michele Bacci, "Identity Markers in the Art of Fourteenth Century Famagusta," in Crusader to Venetian Famagusta: 'The Harbour of all this Sea and Realm,' eds. Coureas, Kiss, Walsh, 150-55; and Michalis Olympios, "The Shifting Mantle of Jerusalem: Ecclesiastical Architecture in Lusignan Famagusta," in Weyl Carr, Famagusta, 157-8. The chronological relation of nave and aisles, certainly executed in two or three phases, has not been sufficiently investigated until now.

14. On the question of early groin vaults in Cypriot churches, see also Olympios, "The Shifting Mantle," 103-105.

15. In Famagusta, the church of Saints Peter and Paul preserves rests of such a lime wash, combined with painted masonry joints (following exactly the factual ones), in the southwest of the interior.

16. Bacci's suggestion to see Latin piscinae as main inspiration is generally convincing (Bacci, "Armenian Church," 491). However, no piscinae in Famagusta resemble the niche in the Armenian Church: they are either not decorated with tracery at all, or the tracery is much more elaborate, as is the case in the Latin cathedral. 
17. Bacci, "Armenian Church," 490; in Saint George Exorinos especially the elbow-shaped corbels, unique in Cyprus but frequently used in the Holy Land, prove the close relation: Bacci, "Syrian, Palaiologan, and Gothic," 209.

18. Bacci, "Armenian Church," 490, mainly referring to the castle chapels studied by Robert W. Edwards, "Ecclesiastical architecture in the fortifications of Armenian Cilicia," Dumbarton Oaks papers/ Dumbarton Oaks Center for Byzantine Studies 36 (1982); and Edwards, "Ecclesiastical architecture in the fortifications of Armenian Cilicia: Second report," Dumbarton Oaks papers/ Dumbarton Oaks Center for Byzantine Studies 37 (1983).

19. Curiously, a similar design can be reconstructed for the monastic church of Ain-Karim, which belonged to an Armenian community in the thirteenth century. Denys Pringle, The Churches of the Crusader Kingdom of Jerusalem: A corpus, 4 vols. (Cambridge, New York: Cambridge University Press, 1993-2009), vol. 1, 40-41. For Tortosa see Paul Deschamps, Romanik im Heiligen Land: Burgen und Kirchen der Kreuzfahrer (Würzburg: ZodiaqueEchter, 1992), 268-78, for Giblet: Deschamps, Romanik, 263-68.

20. Aimoun: Deschamps, Romanik im Heiligen Land, 279-80; Lévon Nordiguian and Jean Claude Voisin, Châteaux et églises du Moyen Age au Liban (Liban: Editions Terre du Liban; Editions TransOrient, 1999), 363-364; Tall Qaimun: Pringle, Churches of the Crusader Kingdom, vol. 2, 160.

21. Camille Enlart, Les monuments des croisés dans le royaume de Jérusalem: Architecture religieuse et civile, 4 vols. (Paris: P. Geuthner, 1925-1927), vol. 1, 93 and fig. 182.

22. Ibid., vol. 1, 63 and pl. 169.

23. Pringle, Churches of the Crusader Kingdom, 368-370. He dates the church to the mid-twelfth century, but admits that an erection after 1244 could be possible.

24. Bacci, "Armenian Church," 491; Edwards, "Ecclesiastical architecture 1," 164: "Frequently [in the chapels of Armenian Cilicia, T.K.], a niche will appear in the north wall of the nave (and occasionally in the south wall) near the junction with the apse."

25. Enlart, L'art gothique, 365-6.

26. Plagnieux and Soulard, "Famagouste. L'architecture religieuse," 258-60. On the question of the identification of the church through written sources and the translation of the name, see also Chap. X of Nicholas Coureas and Chap. X of Dickran Kouymjian in this volume 
27. Bacci, "Armenian Church," 420; Langdale and Walsh, "Armenian Church," 15; Olympios, "The Shifting Mantle" 107, fn. 61.

28. For the issue of diverse Armenian Churches attested in sources of the thirteenth and fourteenth centuries, see also Chap. 3 of Dickran Kouymjian in this volume.

29. Olympios, "The Shifting Mantle," 105-120.

30. See Kaffenberger, "Evoking a distant past"; for a brief discussion of the issue and previously proposed dates.

31. Bacci, "Syrian, Palaiologan, and Gothic," 210.

32. Mentions of Armenian Churches before the early fourteenth century certainly refer to different buildings or an older structure on the same site-see Chap. 3 of Dickran Kouymjian for this aspect.

33. I wish to thank Michalis Olympios for pointing out this problematic fact.

34. Admittedly, the architecture of the second half of the thirteenth century in the Levant is hardly known, so referring to the Levantine architecture means discussing buildings, which were erected around a century earlier.

35. Michalis Olympios, "Saint George of the Greeks and Its Legacy: A Facet of Urban Greek Church Architecture in Lusignan Cyprus," in Weyl Carr, Famagusta, p 177.

36. This thought of a shared pool of masons, erecting churches for different denominations in a rather similar architectural language, could possibly be paralleled with the (later) situation concerning the painted decoration. Here, as well, the multilayered environment of the city became visible through the utilization of forms deriving from various traditions, also adapted to the specific situation. See Chap. 4 of Michele Bacci on the painted decoration of the church for a discussion of this aspect.

37. Enlart, L'art gothique, 367: "une seconde chapelle dont il reste une abside insignifiante avec moulure gothique à la corniche," translation quoted after Enlart, Gothic art, 287.

38. For the GPR images, see Chap. 10 of Francisco Fernandes in this volume. The historic images can be found in the Mogabgab Photographic Archive (especially A.7198, A.9599, A.10758).

39. This is observable in the Armenian mainland (e.g., Goschawank with three churches and four separate chapels, all dating from the twelfth to thirteenth centuries-see Jean-Michel Thierry, Armenien im Mittelalter, lst ed., Die Welt des Mittelalters 
(Regensburg, Saint-Léger-Vauban: Schnell + Steiner; Zodiaque, 2002), p 230-32) as well as in the Armenian compounds of Jerusalem (e.g., Cathedral of Saint James the Great with the separate chapel of the Holy Apostles-see Pringle, Churches of the Crusader Kingdom, Vol III, 168-82).

40. Thierry, Armenien im Mittelalter, 207.

41. Ibid., 288-The ruins of the only partly preserved monastery, Akner, are hardly investigated. The remains of the church indicate a retrospective style rather resembling Late Antique structures, while the monastic buildings are all but gone.

42. On the churches, see Pringle, Churches of the Crusader Kingdom, vol. 3, 212-16, 367-71.

43. Giorgios Dellas, "Néa stoicheía gia éna monastíri sti mesaionikí póli tis Ródou: New Evidence on a Monastery in the Medieval City of Rhodes," Deltion tes Christianikes Archaiologikes Hetaireias 21 (2000). The monastery consists of an often-altered church and, to the east, a courtyard with surrounding buildings. One access leads directly into the church, while the two southern doorways link the monastic building with Omirou Street through narrow lanes.

\section{BIBLIOGRAPHY}

Bacci, Michele. "Syrian, Palaiologan, and Gothic Murals in the "Nestorian" Church of Famagusta." Deltion tes Christianikes Archaiologikes Hetaireias 27 (2006): 207-20.

- "The Armenian Church in Famagusta and its Mural Decoration: Some Iconographic Remarks." Hask hayagitakan taregirk 11 (2009): 489-508.

—. "Identity Markers in the Art of Fourteenth Century Famagusta." In Coureas; Kiss; Walsh, Crusader to Venetian Famagusta: 'The Harbour of all this Sea and Realm', 145-58.

Bonato, Lucie and Rita Severis, eds. Along the Most Beautiful Path in the World: Edmond Duthoit and Cyprus. Nicosia, 1999.

Coureas, Nicholas, Tamás Kiss, and Michael J. K. Walsh, eds. Crusader to Venetian Famagusta: 'The Harbour of all this Sea and Realm'. Budapest, 2014.

De Vaivre, Jean-Bernard. "Identifications hasardeuses et datation de monuments à Famagouste le cas des 'églises jumelles des templiers et des hospitaliers'." Comptes rendus des séances de l'Académie des Inscriptions et Belles-Lettres 146 (2002): 45-55.

- ed. Monuments médiévaux de Chypre: Photographies de la mission de Camille Enlart en 1896. Paris: ACHCByz, 2012. 
Dellas, Giorgios. "Néa stoicheía gia éna monastíri sti mesaionikí póli tis Ródou: New Evidence on a Monastery in the Medieval City of Rhodes." Deltion tes Christianikes Archaiologikes Hetaireias 21 (2000): 43-54.

Deschamps, Paul. Romanik im Heiligen Land: Burgen und Kirchen der Krenzfahrer. Würzburg: Zodiaque-Echter, 1992.

Edwards, Robert W. "Ecclesiastical architecture in the fortifications of Armenian Cilicia." Dumbarton Oaks papers / Dumbarton Oaks Center for Byzantine Studies 36 (1982): 155-76.

- "Ecclesiastical architecture in the fortifications of Armenian Cilicia: Second report." Dumbarton Oaks papers / Dumbarton Oaks Center for Byzantine Studies 37 (1983): 123-46.

Enlart, Camille. L'art gothique et la renaissance en Chypre. 2 vols. Paris: Leroux, 1899.

- Les monuments des croisés dans le royaume de Jérusalem: Architecture religieuse et civile. 4 vols. Paris: P. Geuthner, 1925-1927.

- Gothic art and the Renaissance in Cyprus [L'art gothique et la Renaissance en Chypre (transl. by David Hunt)]. 1899. London: Trigraph in association with the A.G. Leventis Foundation, 1987.

Kaffenberger, Thomas. "Evoking a distant past? The chevron motif as an emblematic relic of Crusader architecture in late medieval Cyprus." In Proceedings of the MedWolds Congress 2014., forthcoming.

—. "Harmonizing the Sources: An Insight into the Appearance of the Hagios Georgios Complex at Various Stages of its Building History." In Coureas; Kiss; Walsh, Crusader to Venetian Famagusta: 'The Harbour of all this Sea and Realm'.

Langdale, Allan, and Michael J. K. Walsh. "The Architecture, Conservation History, and Future of the Armenian Church of Famagusta, Cyprus." Chronos. Revue d'Histoire de l'Université de Balamand 19 (2009): 7-31.

Nordiguian, Lévon, and Jean C. Voisin. Châteaux et eglises du Moyen Age au Liban. Liban: Editions Terre du Liban; Editions Trans-Orient, 1999.

Olympios, Michalis. "Saint George of the Greeks and Its Legacy: A Facet of Urban Greek Church Architecture in Lusignan Cyprus." In Weyl Carr, Famagusta, 143-202.

_ . "The Shifting Mantle of Jerusalem: Ecclesiastical Architecture in Lusignan Famagusta." In Weyl Carr, Famagusta, 75-142.

Plagnieux, Philippe, and Thierry Soulard. "Famagouste. L'architecture religieuse." In L'art gothique en Chypre. Edited by Jean-Bernard De Vaivre, 121-296. Paris: Boccard, 2006.

Pringle, Denys. The Churches of the Crusader Kingdom of Jerusalem: A corpus. 4 vols. Cambridge, New York: Cambridge University Press, 1993-2009.

Thierry, Jean-Michel. Armenien im Mittelalter. 1st ed. Die Welt des Mittelalters. Regensburg, Saint-Léger-Vauban: Schnell + Steiner; Zodiaque, 2002. 
Uluca Tumer, Ege. "Twentieth-century restorations to the medieval and Renaissance monuments of Famagusta." In Medieval and Renaissance Famagusta: Studies in architecture, art and history. Edited by Nicholas Coureas, Peter W. Edbury and Michael J. K. Walsh, 217-34. Farnham: Ashgate, 2012. Weyl Carr, Annemarie, ed. Famagusta: Art and architecture. Volume 1. Mediterranean Nexus 1100-1700 2. Turnhout: Brepols, 2014. 